\title{
Spectroscopic (IR, Raman, UV-Vis) study and thermal analysis of 3d- metal complexes with 4-imidazolecarboxylic acid
}

\author{
Grzegorz Świderski ${ }^{1}$ (1) $\cdot$ Agnieszka Zofia Wilczewska $^{2} \cdot$ Renata Świsłocka $^{1} \cdot$ Monika Kalinowska $^{1} \cdot$ \\ Włodzimierz Lewandowski ${ }^{1}$
}

Received: 30 October 2017 / Accepted: 3 July 2018/ Published online: 16 July 2018

(C) The Author(s) 2018

\begin{abstract}
In this work, the spectroscopic (IR, Raman, UV-Vis) and thermal properties of 3d metal complexes with 4-imidazolecarboxylic acid were studied in order to determine the effect of 3d metals [i.e., $\mathrm{Mn}$ (II), $\mathrm{Fe}$ (III), $\mathrm{Co}$ (II), Ni(II), $\mathrm{Cu}$ (II), $\mathrm{Zn}(\mathrm{II})]$ on the electronic structure and physicochemical properties of the ligand. The spectroscopic studies showed that the 3d-transition metals stabilize the electronic system of 4-imidazolecarboxylic acid. Similar results were obtained previously for benzoic and pyridinecarboxylic acids. The complexes synthesized in an aqueous medium were hydrated, as determined by the elemental and thermogravimetric analysis. The complexes of 4-imidazolecarboxylic acid have the general formula: $\mathrm{M}\left(\mathrm{C}_{3} \mathrm{~N}_{2} \mathrm{H}_{3} \mathrm{COO}\right)_{\mathrm{x}} \cdot \mathrm{nH}_{2} \mathrm{O}$ where $\mathrm{M}=\mathrm{Mn}, \mathrm{Fe}, \mathrm{Co}, \mathrm{Ni}, \mathrm{Cu}, \mathrm{Zn}, x=3$ for iron complex, $x=2$ for other complex and $n=0-3$. Thermogravimetric analysis conducted in oxygen atmosphere showed that the complexes decompose to metal oxides. During the thermal decomposition process carbon monoxide, carbon dioxide and imidazole ring degradation products are released.
\end{abstract}

Keywords 4-Imidazolecarboxylic acid · 3d-metal complexes · Thermal analysis · 4-Imidazolecarboxylates · IR and Raman spectra

\section{Introduction}

4-Imidazolecarboxylic acid is a derivative of imidazole which is of great biological importance ligand. Imidazole is a structural unit of constructive histidine, histamine, and it is a part of purines which are molecules showing important biological functions in the human body. Some of the imidazole derivatives possess anti-inflammatory, antituberculotic, antimicrobial, antimycotic, antiviral and even antitumor activity [1-7]. Tinidazole, ornidazole and metronidazole are known as antimicrobials and antiparasites since the mid-1960s [8]. Imidazole and its derivatives are used as fungicides due to their ability to inhibit the

Grzegorz Świderski

g.swiderski@pb.edu.pl

1 Department of Chemistry, Biology and Biotechnology, Bialystok University of Technology, Wiejska 45E Street, 15-351 Białystok, Poland

2 Institute of Chemistry, University of Bialystok, Ciolkowskiego Street 1K, 15-245 Białystok, Poland synthesis of ergosterol and the fungal cell membrane component, and to interfere with the synthesis of triglycerides and phospholipids [9].

The imidazole derivatives easily coordinate 3d-metal ions and are examined for their medical use [10, 11]. Many crystalline structures of $3 \mathrm{~d}$-metals complexes with derivatives of 4-imidazolecarboxylic acid have been described in the literature. A nitrogen atom of the imidazole ring participate in the coordination of metal by ligand (e.g., nitroimidazole complexes with copper, cobalt and zinc [12], 4-imidazoleacetate with manganese [13], 5-methylimidazolecarboxylate with copper [14], cadmium, nickel and cobalt [15], or complexes of 4,5-imidazoledicarboxylic acid with $3 d$ metals $[16,17])$. When the nitrogen atom is in close proximity to the carboxylic group, the metal is coordinated through nitrogen atom and carboxylic group. The five-membered chelate rings are then formed [16-20]. The chelate rings exert a stabilizing effect on the structure of these complexes [19, 20].

Transition metal complexes with imidazolecarboxylic acid derivatives were also tested for thermal stability. 
While manganese, cobalt and nickel complexes with 4,5imidazoledicarboxylic acid decompose comparatively at a lower temperature (around $450{ }^{\circ} \mathrm{C}$ ), zinc and cadmium complexes show a higher temperature of decomposition (around $620^{\circ} \mathrm{C}$ ) to give the end products [17].

Jabłońska-Wawrzecka and others investigated selected transition bivalent metal complexes with 5-carbaldehyde4-methylimidazole. In the case of the complexes with $\mathrm{Co}(\mathrm{II}), \mathrm{Mn}(\mathrm{II}), \mathrm{Cd}(\mathrm{II})$ and $\mathrm{Zn}(\mathrm{II})$, the decomposition process was studied in nitrogen atmosphere, whereas for Ni(II) complex, the process was conducted in argon. The decomposition process occurred in three main stages, except for $\mathrm{Zn}$ (II) complex (two stages of decomposition were shown) in temperature range of 353-1163 K. The final products of decomposition process were $\mathrm{CoO}, \mathrm{MnO}$, $\mathrm{Cd}, \mathrm{ZnN}_{4}, \mathrm{NiN}_{3}$ [21].

In our earlier work, we studied the structure and thermal properties of metal complexes with nitrogen-containing heteroaromatic acids, i.e., pyridinecarboxylic and pyrazinecarboxylic acids [22, 23]. In this work, the thermal properties of 4-imidazolecarboxylic acid complexes have been investigated. The structure of synthesized complexes was determined by means of infrared, Raman and UV-Vis spectroscopy and theoretical calculations.

\section{Experimental}

\section{Sample preparation}

The sodium salt of 4-imidazolecarboxylate was prepared by dissolving the appropriate weighed amount of acid ( $1 \mathrm{mmol})$ in aqueous solution of sodium hydroxide $\left(10 \mathrm{~mL}, 0.1 \mathrm{~mol} \mathrm{~L}^{-1}\right)$ in a stoichiometric molar ratio ligand/metal $-1: 1$. The reaction was carried out in a water bath at $70{ }^{\circ} \mathrm{C}$. The zinc complex of 4-imidazolecarboxylic acid was received by addition the appropriate amount of an aqueous solution of zinc chloride $\left(5 \mathrm{~mL}, 5 \times 10^{-4}\right.$ mol L ${ }^{-1}$ ) to a pre-prepared solution of sodium salt of 4-imidazolecarboxylic acid (containing $1 \mathrm{mmol}$ of sodium salt). Then, solution was shaken on a thermostatic shaker at $70{ }^{\circ} \mathrm{C}$ for $1 \mathrm{~h}$. In this mixture, the molar ratio of sodium salt of 4-imidazolecarboxylic acid to metal ion was 2:1. The solutions were left for $24 \mathrm{~h}$ at room temperature. The precipitates were then filtered, and the solution was rinsed with deionized water until all chloride ions were washed out. The solid substances have been dried for $24 \mathrm{~h}$ in an oven at $30{ }^{\circ} \mathrm{C}$. For each complex $(\mathrm{Mn}, \mathrm{Co}, \mathrm{Ni}, \mathrm{Cu})$, the procedure was the same. The iron (III) complex was obtained by adding the solution iron (III) chloride $\left(3.33 \mathrm{~mL}, 5 \times 10^{-4} \mathrm{~mol} \mathrm{~L}^{-1}\right)$ to a pre-prepared solution of sodium salt of 4-imidazolecarboxylic acid (containing $1 \mathrm{mmol}$ of sodium salt). The further procedure was analogous to the synthesis of the other complexes. The yield of the synthesis process was about $60-70 \%$.

\section{Methods}

The products of dehydration and decomposition processes have been determined from the TG curves. Thermogravimetric analysis (TGA) was performed using a Mettler Toledo Star TGA/DSC1 unit. The process was conducted in an inert gas atmosphere (argon) and in an oxygen atmosphere. Samples $(2-4 \mathrm{mg}$ ) were placed in aluminum pans and heated from 50 to $850{ }^{\circ} \mathrm{C}$ with a heating rate of $10{ }^{\circ} \mathrm{C} \mathrm{min}^{-1}$. The TG, DTG and DSC curves were registered. The elemental analysis was carried out using the CHN 2400 Perkin Elmer Analyzer.

The FT-IR spectra were recorded with an Alfa (Bruker) spectrometer within the range of $400-4000 \mathrm{~cm}^{-1}$. Samples were measured in $\mathrm{KBr}$ matrix pellets and by the use of ATR technique. FT-Raman spectra of solid samples were recorded in the range of $400-4000 \mathrm{~cm}^{-1}$ with a MultiRam (Bruker) spectrometer. To calculate optimized geometrical structures of 4-imidazolecarboxylic acid, sodium salts, copper complex and cobalt complex, the quantum-mechanical method were used: density functional (DFT) hybrid method B3LYP with non-local correlation provided by Lee-Young-Parr expression. All calculations were carried out in a functional base $6-311++\mathrm{G}(\mathrm{d}, \mathrm{p})$. Calculations were performed using the Gaussian 09 package [24]. Experimental spectra were interpreted in terms of the calculated ones at DFT method in B3LYP/6-311++G(d,p) level and on the basis of the literature data $[25,26]$.

Theoretical wavenumbers were scaled according to the formula: $\quad v_{\text {scaled }}=0.98 \cdot v_{\text {calculated }}$ for B3LYP/6$311++G(d, p)$ level method [27]. Spectral assignments used the normal oscillation of the imidazole ring measured using DFT.

\section{Results}

\section{IR and Raman spectra}

The wavenumbers, intensities and assignments for the bands occurring in the vibrational spectra of the studied 4-imidazolecarboxylic acid and 4-imidazolecarboxylates were presented in Table 1. The normal vibrations for imidazole ring calculated at the DFT level are shown in Fig. 1. The spectrum assignment was based on literature data $[25,26]$ and theoretical calculations for 4-imidazolecarboxylic acid, its sodium salt, copper and cobalt complex. The monomer of 4-imidazolecarboxylic acid may be present in two conformations: s-cis (syn) and s-trans (anti) (Fig. 2). The more stable one is the anti-monomer. 
Table 1 Wavenumbers $/ \mathrm{cm}^{-1}$, intensities and assignments of bands occurring in the IR ( $\mathrm{KBr}$ and DFT) and Raman spectra of 4-imidazolecarboxylic acid and sodium, manganese, nickel, cobalt, copper, zinc, iron 4-imidazolecarboxylates

\begin{tabular}{|c|c|c|c|c|c|c|c|c|c|c|c|}
\hline \multicolumn{6}{|c|}{ 4-Imidazolecarboxylic acid } & \multicolumn{6}{|c|}{ 4-Imidazolecarboxylates } \\
\hline \multirow{2}{*}{\multicolumn{2}{|c|}{ Exp. }} & \multirow{2}{*}{\multicolumn{2}{|c|}{$\begin{array}{l}\text { Conformer syn } \\
\text { Calc. }\end{array}$}} & \multirow{2}{*}{\multicolumn{2}{|c|}{$\begin{array}{l}\text { Conformer anti } \\
\text { Calc. }\end{array}$}} & \multicolumn{4}{|l|}{ Sodium } & \multirow{2}{*}{\multicolumn{2}{|c|}{$\frac{\text { Zinc }}{\text { Exp. }}$}} \\
\hline & & & & & & \multicolumn{2}{|l|}{ Exp. } & \multicolumn{2}{|l|}{ Calc. } & & \\
\hline IR $\mathrm{KBr}$ & Raman & IR & Int. & IR & Int. & IR $\mathrm{KBr}$ & Raman & IR & Int. & IR KBr & Raman \\
\hline \multirow{4}{*}{$\begin{array}{l}1620 \mathrm{vs} \\
1595 \mathrm{~s}\end{array}$} & $1621 \mathrm{vs}$ & 1734 & 532.0 & 1763.0 & 489.0 & & & & & & \\
\hline & & & & & & & & & & & \\
\hline & & & & & & $1576 v s$ & $1567 \mathrm{vs}$ & 1558 & 117.79 & $1602 \mathrm{vs}$ & $1636 w$ \\
\hline & & & & & & & & & & & $1572 s$ \\
\hline $1524 \mathrm{~m}$ & $1536 \mathrm{~m}$ & 1555 & 46.4 & 1560 & 108.4 & & & 1537 & 485.3 & $1520 \mathrm{~s}$ & $1523 w$ \\
\hline $1497 \mathrm{~m}$ & $1506 \mathrm{vs}$ & 1444 & 19.4 & 1445 & 36.8 & $1507 \mathrm{w}$ & $1509 w$ & 1445 & 64.78 & $1508 \mathrm{~s}$ & \\
\hline \multirow[t]{2}{*}{$1446 \mathrm{~s}$} & $1451 \mathrm{~s}$ & 1412 & 21.4 & 1413 & 41.3 & $1457 \mathrm{~m}$ & $1465 \mathrm{~s}$ & 1406 & 229.06 & $1456 \mathrm{~s}$ & $1453 \mathrm{vs}$ \\
\hline & & & & & & $1420 \mathrm{~m}$ & $1399 w$ & 1385 & 217 & $1388 v s$ & $1389 v s$ \\
\hline $1418 \mathrm{~m}$ & & 1383 & 207.8 & 1355 & 72.6 & & & & & & \\
\hline \multirow[t]{2}{*}{1372 vs } & $1365 \mathrm{~s}$ & 1313 & 4.1 & 1312 & 47.0 & $1340 \mathrm{vw}$ & & 1320 & 8.61 & $1333 \mathrm{~m}$ & $1336 \mathrm{~m}$ \\
\hline & & 1241 & 0.8 & 1244 & 3.6 & $1311 w$ & $1314 \mathrm{~m}$ & & & & $1308 \mathrm{vw}$ \\
\hline $1239 \mathrm{~m}$ & $1233 m$ & 1230 & 23.2 & 1208 & 52.4 & $1236 w$ & $1249 \mathrm{~m}$ & 1235 & 12.64 & $1243 \mathrm{~m}$ & $1242 \mathrm{w}$ \\
\hline $1207 \mathrm{~m}$ & $1211 \mathrm{~s}$ & 1138 & 145.2 & 1132 & 79.6 & $1217 \mathrm{w}$ & $1210 w$ & 1192 & 39.9 & $1221 w$ & $1219 w$ \\
\hline $1166 \mathrm{~m}$ & $1173 \mathrm{~m}$ & 1104 & 351.5 & 1103 & 238.0 & $1154 w$ & $1162 \mathrm{w}$ & 1118 & 18.45 & $1171 w$ & $1169 \mathrm{~m}$ \\
\hline \multirow[t]{2}{*}{$1098 \mathrm{~m}$} & $1109 w$ & 1081 & 39.7 & 1072 & 63.4 & $1109 w$ & $1108 w$ & 1068 & 59.11 & $1091 w$ & $1087 w$ \\
\hline & & 988 & 27.8 & 976 & 92.9 & $1083 \mathrm{vw}$ & $1087 \mathrm{vw}$ & 995 & 22.11 & $1079 w$ & \\
\hline $1055 w$ & & 915 & 5.8 & 915 & 6.3 & & $1048 \mathrm{vw}$ & 918 & 5.23 & & $1053 \mathrm{vw}$ \\
\hline $990 w$ & $986 \mathrm{~s}$ & 864 & 9.6 & 873 & 8.2 & $994 \mathrm{vw}$ & $994 m$ & & & $1006 \mathrm{~m}$ & $1006 \mathrm{~m}$ \\
\hline $909 w$ & & 825 & 19.6 & 822 & 21.0 & $940 \mathrm{vw}$ & $927 \mathrm{vw}$ & 864 & 8.03 & $928 w$ & $932 w$ \\
\hline \multirow[t]{2}{*}{$891 w$} & & 761 & 44.3 & 754 & 44.8 & & & 806 & 43.99 & & $897 \mathrm{vw}$ \\
\hline & & & & & & $820 \mathrm{~m}$ & $817 w$ & 810 & 27.8 & $826 \mathrm{~s}$ & $850 \mathrm{vw}$ \\
\hline $797 \mathrm{~s}$ & $785 \mathrm{vw}$ & 686 & 44.8 & 680 & 42.8 & $789 w$ & & 792 & 6.72 & $787 \mathrm{~m}$ & $793 \mathrm{vw}$ \\
\hline $780 \mathrm{~s}$ & & 664 & 0.0 & 663 & 2.0 & & & 676 & 1.4 & & \\
\hline \multirow[t]{2}{*}{$721 \mathrm{vw}$} & & 624 & 14.2 & 623 & 3.8 & & $718 v w$ & 628 & 36.6 & & $743 \mathrm{vw}$ \\
\hline & & & & & & $659 w$ & $663 \mathrm{vw}$ & & & $653 m$ & $658 \mathrm{vw}$ \\
\hline $633 \mathrm{~m}$ & & 571 & 110.5 & 562 & 150.4 & $622 w$ & $628 \mathrm{vw}$ & 582 & 65.69 & $617 \mathrm{~m}$ & $621 \mathrm{vw}$ \\
\hline \multirow[t]{2}{*}{$538 \mathrm{~m}$} & & 519 & 89.2 & 516 & 51.4 & $531 w$ & $535 \mathrm{vw}$ & 517 & 5.29 & $555 \mathrm{vw}$ & $550 \mathrm{w}$ \\
\hline & & & & & & $531 \mathrm{~m}$ & & & & $499 m$ & \\
\hline
\end{tabular}

4-Imidazolecarboxylates

\begin{tabular}{|c|c|c|c|c|c|c|c|c|c|c|}
\hline \multirow{2}{*}{\multicolumn{2}{|c|}{$\begin{array}{l}\text { Manganese } \\
\text { Exp. }\end{array}$}} & \multirow{3}{*}{$\begin{array}{l}\text { Nickel } \\
\text { Exp. } \\
\text { IR KBr }\end{array}$} & \multicolumn{3}{|l|}{ Cobalt } & \multicolumn{3}{|l|}{ Copper } & \multirow{3}{*}{$\begin{array}{l}\text { Iron } \\
\text { IR KBr }\end{array}$} & \multirow[t]{3}{*}{ Assignments } \\
\hline & & & \multirow{2}{*}{$\begin{array}{l}\text { Exp. } \\
\text { IR } \mathrm{KBr}\end{array}$} & \multicolumn{2}{|l|}{ Calc. } & \multirow{2}{*}{$\begin{array}{l}\text { Exp. } \\
\text { IR KBr }\end{array}$} & \multicolumn{2}{|l|}{ Calc. } & & \\
\hline IR $\mathrm{KBr}$ & Raman & & & IR & Int. & & IR & Int. & & \\
\hline & & & & & & & & & & $\begin{array}{l}v \mathrm{C}=\mathrm{O} \\
\text { vring }\end{array}$ \\
\hline $1603 v s$ & $1582 \mathrm{~s}$ & $1600 v s$ & $1585 \mathrm{vs}$ & 1698 & 1404.0 & $1623 v s$ & 1699 & 1328.2 & $1637 \mathrm{vs}$ & $v_{\text {asym }} \mathrm{COO}^{-}$ \\
\hline \multirow[t]{2}{*}{$1561 \mathrm{~s}$} & $1550 \mathrm{~s}$ & $1568 \mathrm{~s}$ & $1555 \mathrm{vs}$ & & & $1569 \mathrm{~s}$ & & & $1584 \mathrm{~s}$ & $v_{\text {asym }} \mathrm{COO}^{-}$ \\
\hline & & $1515 \mathrm{~s}$ & $1528 \mathrm{~s}$ & 1571 & 0.0 & $1520 \mathrm{~s}$ & 1569 & 19.5 & $1520 \mathrm{~m}$ & 5 \\
\hline \multirow[t]{2}{*}{$1501 \mathrm{~s}$} & $1493 m$ & & $1514 \mathrm{~s}$ & 1501 & 138.5 & & 1499 & 200.9 & $1497 \mathrm{~m}$ & 6 \\
\hline & $1444 \mathrm{~s}$ & & $1463 \mathrm{~s}$ & 1431 & 0.0 & $1449 \mathrm{~s}$ & 1432 & 30.2 & $1462 \mathrm{~m}$ & 7 \\
\hline $1429 \mathrm{~s}$ & & $1419 \mathrm{~s}$ & $1406 v s$ & 1341 & 22.6 & $1355 \mathrm{v}$ & 1340 & 46.0 & $1369 \mathrm{vs}$ & $v_{\mathrm{sym}} \mathrm{COO}^{-}$ \\
\hline $1406 \mathrm{~s}$ & $1389 \mathrm{vs}$ & 1381vs & & 1279 & 470.8 & & 1277 & 685.5 & $1354 \mathrm{~s}$ & $\begin{array}{l}v_{\mathrm{sym}} \mathrm{COO}^{-} \\
\beta \mathrm{OH}\end{array}$ \\
\hline
\end{tabular}


Table 1 (continued)

\begin{tabular}{|c|c|c|c|c|c|c|c|c|c|c|}
\hline \multicolumn{11}{|c|}{ 4-Imidazolecarboxylates } \\
\hline \multirow{2}{*}{\multicolumn{2}{|c|}{$\begin{array}{l}\text { Manganese } \\
\text { Exp. }\end{array}$}} & \multirow{3}{*}{$\begin{array}{l}\text { Nickel } \\
\text { Exp. } \\
\text { IR KBr }\end{array}$} & \multicolumn{3}{|l|}{ Cobalt } & \multicolumn{3}{|l|}{ Copper } & \multirow{3}{*}{$\begin{array}{l}\text { Iron } \\
\text { IR KBr }\end{array}$} & \multirow[t]{3}{*}{ Assignments } \\
\hline & & & \multirow{2}{*}{$\begin{array}{l}\text { Exp. } \\
\text { IR KBr }\end{array}$} & \multicolumn{2}{|l|}{ Calc. } & \multirow{2}{*}{$\begin{array}{l}\text { Exp. } \\
\text { IR KBr }\end{array}$} & \multicolumn{2}{|l|}{ Calc. } & & \\
\hline IR $\mathrm{KBr}$ & Raman & & & IR & Int. & & IR & Int. & & \\
\hline $1320 \mathrm{~m}$ & $1320 w$ & $1336 \mathrm{~m}$ & $1334 \mathrm{~m}$ & & & $1333 \mathrm{~s}$ & & & $1328 \mathrm{~m}$ & $\begin{array}{l}8 \\
9\end{array}$ \\
\hline \multicolumn{2}{|l|}{$1235 \mathrm{~s}$} & $1238 \mathrm{~m}$ & $1234 \mathrm{~s}$ & 1215 & 20.2 & $1241 w$ & 1219 & 28.7 & $1251 \mathrm{w}$ & $\alpha_{\text {ring }}$ \\
\hline $1219 \mathrm{~m}$ & $1217 w$ & $1212 \mathrm{~m}$ & & 1185 & 262.3 & $1211 \mathrm{~m}$ & 1187 & 235.9 & $1208 \mathrm{~m}$ & 10 \\
\hline $1137 w$ & $1163 \mathrm{vw}$ & 113vw3 & $1190 w$ & 1120 & 39.3 & $1175 \mathrm{~m}$ & 1126 & 58.7 & $1180 \mathrm{~m}$ & 11 \\
\hline \multirow[t]{3}{*}{$1098 \mathrm{~m}$} & $1117 \mathrm{v}$ & & $1102 \mathrm{~m}$ & 1054 & 88.6 & & 1054 & 91.3 & & 12 \\
\hline & $1082 \mathrm{vw}$ & $1085 \mathrm{~m}$ & $1093 \mathrm{~m}$ & 996 & 22.5 & $1092 \mathrm{w}$ & 992 & 35.6 & $1095 \mathrm{~m}$ & 13 \\
\hline & $1054 \mathrm{vw}$ & & & 939 & 11.3 & & 939 & 9.2 & & 14 \\
\hline $987 \mathrm{~m}$ & $968 \mathrm{w}$ & $997 \mathrm{~m}$ & $1008 \mathrm{~m}$ & & & $1014 \mathrm{~s}$ & & & $1010 \mathrm{~m}$ & 15 \\
\hline \multirow[t]{2}{*}{$939 w$} & & $933 w$ & $930 \mathrm{~m}$ & 826 & 37.5 & $938 \mathrm{~m}$ & 832 & 40.2 & $933 w$ & 16 \\
\hline & $908 \mathrm{vw}$ & & & 811 & 76.8 & $904 w$ & 806 & 2.5 & $888 w$ & 17 \\
\hline \multirow[t]{2}{*}{$837 \mathrm{~s}$} & $851 w$ & $830 \mathrm{~m}$ & $845 \mathrm{~m}$ & 807 & 21.4 & $854 \mathrm{~m}$ & & & & $\beta_{\mathrm{sym}} \mathrm{COO}^{-}$ \\
\hline & $822 \mathrm{vw}$ & $812 \mathrm{~m}$ & $820 \mathrm{~m}$ & 800 & 0.0 & $820 \mathrm{~m}$ & 797 & 87.7 & $823 w$ & $\beta_{\mathrm{sym}} \mathrm{COO}^{-}$ \\
\hline \multirow[t]{3}{*}{$779 \mathrm{~s}$} & $781 \mathrm{vw}$ & $783 \mathrm{~s}$ & $792 \mathrm{~m}$ & 751 & 23.6 & $793 m$ & 752 & 25.2 & $789 w$ & 18 \\
\hline & & & & 659 & 9.2 & & 655 & 0.1 & & $\beta \mathrm{COOH}$ \\
\hline & $728 \mathrm{vw}$ & $717 \mathrm{~s}$ & $732 w$ & 625 & 32.9 & & 624 & 63.7 & $668 w$ & 19 \\
\hline $660 \mathrm{~s}$ & $668 \mathrm{vw}$ & $659 \mathrm{~s}$ & $659 \mathrm{~m}$ & & & $654 \mathrm{~m}$ & & & $654 \mathrm{~m}$ & $\gamma_{\mathrm{sym}} \mathrm{COO}^{-}$ \\
\hline $615 \mathrm{~m}$ & $607 \mathrm{vw}$ & $612 \mathrm{~m}$ & $610 \mathrm{~m}$ & & & $616 \mathrm{~m}$ & 564 & 175.3 & $619 w$ & 20 \\
\hline $544 w$ & $562 \mathrm{vw}$ & $569 \mathrm{~m}$ & $554 w$ & 542 & 247.3 & $575 w$ & 557 & 2.0 & $561 \mathrm{vw}$ & $\varphi_{\text {ring }}$ \\
\hline $483 \mathrm{~m}$ & & $501 \mathrm{~m}$ & $491 \mathrm{~m}$ & 512 & 293.5 & $524 \mathrm{~m}$ & & & $516 \mathrm{~m}$ & $\beta_{\text {asym }} \mathrm{COO}^{-}$ \\
\hline
\end{tabular}

$v$ : stretching; $\beta$ : in plane; $\gamma$ : out of plane deformations; $\alpha$ : skeleton vibration in plane; $\phi$ : skeleton vibration out of plane; s: strong; vs: very strong; $\mathrm{m}$ : medium; w: weak; vw: very weak

In the spectra of 4-imidazolecarboxylic acid the characteristic bands derived from the vibrations of the carboxyl group $v \mathrm{C}=\mathrm{O}$ at 1620 (in the IR spectra) and $1621 \mathrm{~cm}^{-1}$ (in Raman spectra) occurred. The replacement of the carboxylic group hydrogen with a metal ion brought about characteristic changes in the IR and Raman spectra of the metal 4-imidazolecarboxylates in comparison with the spectra of ligand. One can observe disappearance of bands of the symmetric and asymmetric valence vibrations of carboxylic group and appearance of bands of the asymmetric and symmetric vibrations of the carboxylate group $v_{\text {asym }}(\mathrm{COO}), v_{\text {sym }}(\mathrm{COO})$, as well as $\beta_{\text {asym }}\left(\mathrm{COO}^{-}\right), \beta_{\text {sym }}(-$ $\mathrm{COO}^{-}$), and disappearance or changes in positions and intensities of some aromatic bands (Table 1, Fig. 3).

In the IR spectra of 4-imidazolecarboxylates, the wavenumbers of asymmetric $\left(v_{\text {asym }} \mathrm{COO}^{-}\right)$and symmetric $\left(v_{\text {sym }} \mathrm{COO}^{-}\right)$stretching vibrations of carboxylate occur in the range of $1550-1637$ and $1369-1429 \mathrm{~cm}^{-1}$, respectively (see Tables 1,2). Asymmetric and symmetric deformation vibrations of the carboxylate group $\left(\beta_{\text {asym }} \mathrm{COO}^{-}\right)$and $\left(\beta_{\mathrm{sym}} \mathrm{COO}^{-}\right)$are located, respectively, in the range of
483-531 and $817-851 \mathrm{~cm}^{-1}$ in the IR spectra of 4-imidazolecarboxylates.

On the basis of the differences between the wavenumbers of the asymmetric and symmetric stretching vibrations of the carboxylate group $\mathrm{COO}^{-}$, some assumption about the type of metal-ligand coordination might be stated $[28,29]$. For the monodentate geometry, the bands for $\left(v_{\text {asym }} \mathrm{COO}^{-}\right)$and $\left(v_{\text {sym }} \mathrm{COO}^{-}\right)$in the complex are shifted to higher and lower wavenumbers, respectively, or $\left(\Delta v \mathrm{COO}^{-}\right)_{\text {studied complex }} \gg\left(\Delta v \mathrm{COO}^{-}\right)_{\text {sodium salt }}$. This type of coordination has been observed for all complexes (Table 2).

In the aromatic ring of imidazole, the nitrogen-containing free electrons may be involved in coordinating the metal. In the complexes of manganese, iron, cobalt, copper, nickel and zinc, there is a monodentate type of coordination through the carboxylate anion. The metal is simultaneously coordinated by the ligand through the nitrogen atom (Figs. 4, 5). The changes in the wavenumbers of the band assigned to the vibrations of the nitrogen-carbon prove the engagement of nitrogen in metal coordination. 

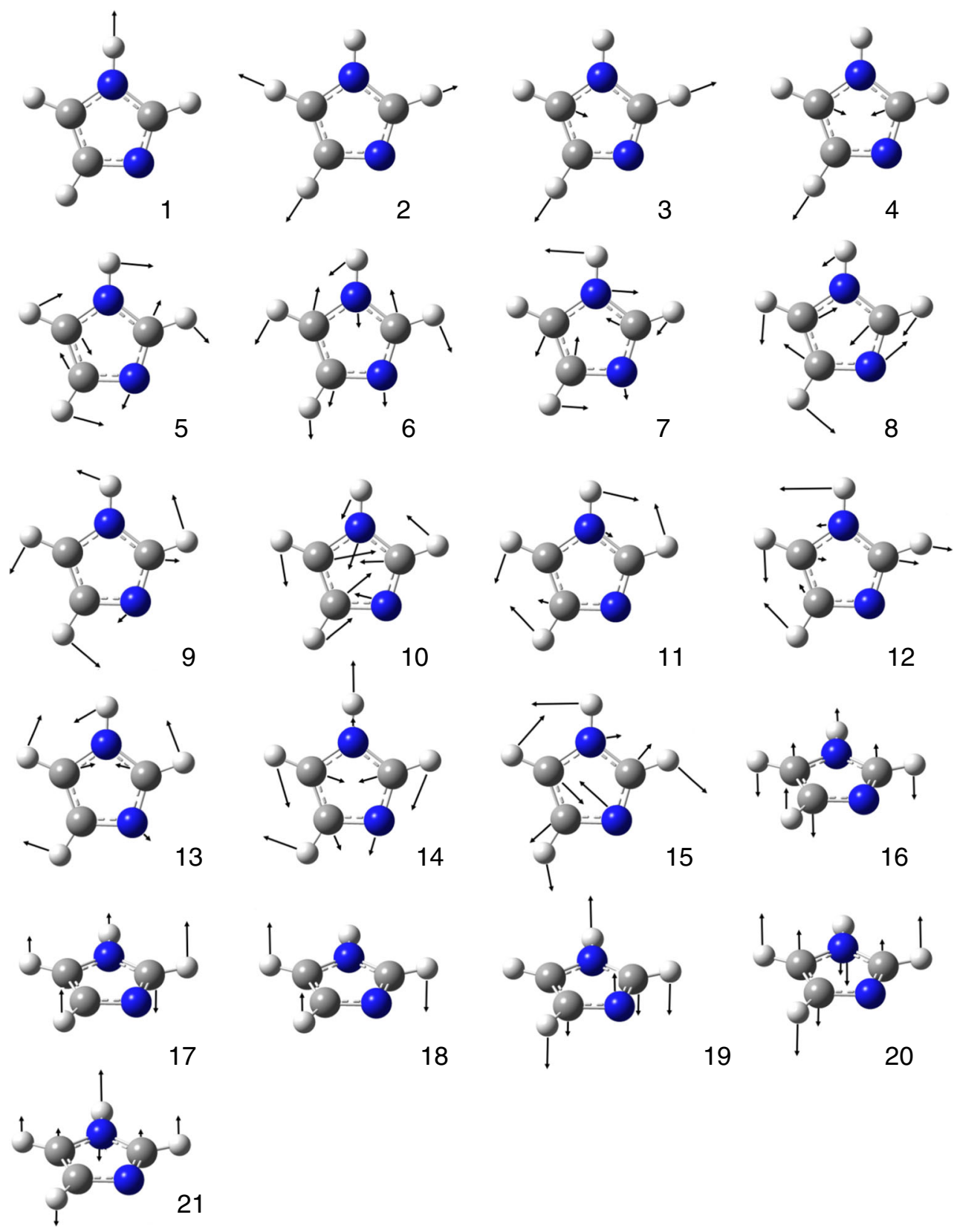

18
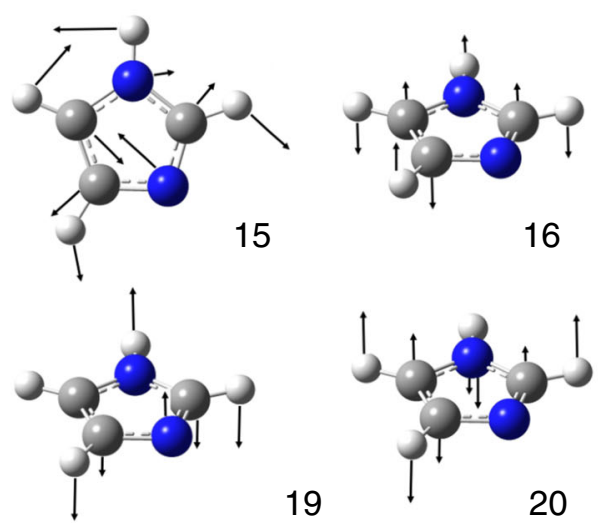

Fig. 1 Normal modes of vibrations for imidazole (calculated B3LYP/6-311++G(d,p))

The coordination of metal through the nitrogen atom of the imidazole ring causes significant shift or disappearance of bands assigned to the $\mathrm{C}=\mathrm{N}$ vibrations (bands 6, 7 and 8) from the IR spectra of complexes compared to the spectrum of ligand (Table 1, Fig. 3). For example, the band no. 7 originated from the $\mathrm{CN}$ stretching vibrations is shifted from 1446 (the IR spectra of acid) to $1456 \mathrm{~cm}^{-1}$ in the IR spectra of zinc complex, $1463 \mathrm{~cm}^{-1}$ in the IR spectra of cobalt, $1449 \mathrm{~cm}^{-1}$ in the IR spectra of copper and $1462 \mathrm{~cm}^{-1}$ in the IR spectra of iron. In the case of manganese and nickel complexes, this band disappears. The band no. 8 derived from the $\mathrm{CN}$ stretching vibrations is shifted from 1372 (in the spectra of acid) to $1333 \mathrm{~cm}^{-1}$ in the IR spectra of zinc complex, $1320 \mathrm{~cm}^{-1}$ in the IR spectra of manganese, $1336 \mathrm{~cm}^{-1}$ in the IR spectra of nickel, $1334 \mathrm{~cm}^{-1}$ in the IR spectra of copper and $1328 \mathrm{~cm}^{-1}$ in the IR spectra of iron. The intensity of this band in the IR spectra of complexes decreases in relation to the IR spectra acid. Many different 4-imidazolecarboxylic acid derivatives have coordinated the metals in analogous way $[12,13,16,17]$.

The structures and infrared vibration wavenumbers for the anhydrous copper complex (Fig. 4) and the cobalt dihydrate complex (Fig. 5) were calculated (DFT/B3LYP/ 

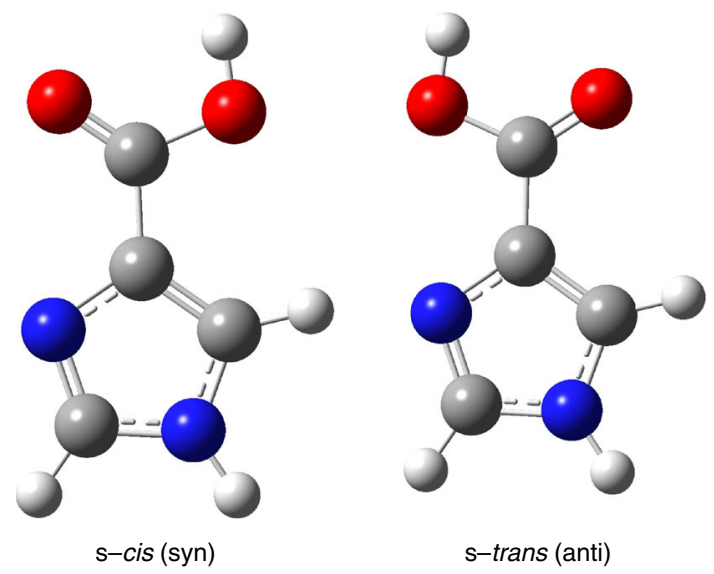

Fig. 2 The structures of 4-imidazolecarboxylic acid monomer (syn and anti conformers)

6-311++) $\mathrm{G}(\mathrm{p}, \mathrm{d})$. (The degree of hydration is in accordance with the thermal and elemental analysis). The calculations were used to detailed assignment of the infrared vibrational bands recorded for the studied complexes. When comparing the spectra of 4-imidazolecarboxylic acid with sodium and 3d-metal 4-imidazolecarboxylates, it has been observed the lower number of bands in the spectra of sodium salt compares the spectra of ligand, whereas in the spectra of the $3 \mathrm{~d}$ metal complexes, the number of band is higher than in the IR spectra of ligand (Table 1). This means that sodium destabilizes the electronic charge distribution in the aromatic ring of 4-imidazolecarboxylic acid, while the $3 \mathrm{~d}$ metals can have a stabilizing effect on the distribution of this charge. Analogous observations have been made for other ligands (aromatic and heteroaromatic acids) - the alkali metals disturb the aromatic system of ligands, while the $3 \mathrm{~d}$ metals stabilize the system [22, 23, 30, 31].

A detailed analysis has shown that some of the bands present in the spectrum of acid are shifted including the following ones: $6, \alpha_{\text {ring }}$ (at about $1239 \mathrm{~cm}^{-1}$ ) $10,11,12$, $13,15,16,17,19, \varphi_{\text {ring }}\left(633 \mathrm{~cm}^{-1}\right)$. A few bands were shifted toward lower values of the wavenumbers in the spectra of the complexes as compared to the acid spectrum. These bands are marked with numbers: 5, 8, 14, 18, 20.

The distribution of the electronic charge in the aromatic ring of the ligand depends on the nature of the metal-ligand bonding. In the case of ionic bonds formed between the ligand and alkali metals, the electronic system in ligand is disturbed. In transition metal complexes, the delocalized covalent bonds are formed between the metal and the ligand. This promotes the delocalization of the electronic charge in the aromatic ring and stabilization of the system. The delocalization of electrons in the central ion has also stabilizing effect on the aromaticity of ligand. A similar effect is observed in the lanthanide complexes [32, 33].

\section{UV study}

In the UV spectra of 4-imidazolecarboxylic acid, one maximum absorbance at $210 \mathrm{~nm}$ occurred in the range of 190-300 nm. In the spectra of the obtained transition metal complexes with 4-imidazolecarboxylic acid, the maximum of absorbance was observed at 225 (manganese 4-imidazolecarboxylate), 222 (nickel and zinc 4-imidazolecarboxylates), 220 (copper and cobalt 4-imidazolecarboxylates) and $209 \mathrm{~nm}$ (iron 4-imidazolecarboxylate). Slight hypochromic effect was observed (Fig. 6).

The bands observed in the UV-Vis spectra correspond to the electron transitions $\pi \rightarrow \pi^{*}$. In the spectra of 4-imidazolecarboxylic acid complexes, bathochromic effect was observed (except for the iron complex). This demonstrates that under the influence of $3 \mathrm{~d}$ metal the electronic system of ligand is stabilized (the aromaticity increases) [30, 31].

\section{Thermal and elemental analysis}

Table 3 shows the results of elemental analysis of synthesized complexes, color of complexes and percent yield of synthesis. The complexes of 4-imidazolecarboxylic acid with transition metal ions have the general formula: $\mathrm{M}\left(\mathrm{C}_{3} \mathrm{~N}_{2} \mathrm{H}_{3} \mathrm{COO}\right)_{\mathrm{x}} \cdot \mathrm{nH}_{2} \mathrm{O}$ where $\mathrm{M}=\mathrm{Mn}, \mathrm{Fe}, \mathrm{Co}, \mathrm{Ni}, \mathrm{Cu}$, $\mathrm{Zn}, x=3$ for iron complex, $x=2$ for other complex and $n=0-3$. Manganese complex was white similarly as the ligand; other complexes were colorful. Synthesis was carried out several times to optimize the synthesis and give reaction yield in the range of $70-85 \%$.

The TG/DTG curves registered in an oxygen atmosphere and argon atmosphere are shown in Fig. 7. The data characteristic for the thermal decomposition of the complexes is collected in Table 4. The thermal decomposition of 4-imidazolecarboxylic acid is a one-step process. The complete decomposition of the ligand occurs at about $270{ }^{\circ} \mathrm{C}$. Generally, the complexes decompose in the two ground stages: the first stage is dehydration of the complexes with the formation of anhydrous compounds, and the second stage is the decomposition of anhydrous compounds connected with oxidation of organic ligands and formation of metal oxides (metal carbonate in the case of decomposition of the manganese complex) - as residues. Similar decomposition products were obtained in the case of thermal decomposition of $3 \mathrm{~d}$ metal complexes with 4,5imidazolecarboxylic acid, i.e., metal oxides: $\mathrm{CoO}, \mathrm{NiO}$, $\mathrm{CuO}, \mathrm{ZnO}$ and $\mathrm{Fe}_{2} \mathrm{O}_{3}$, and in the case of thermal 


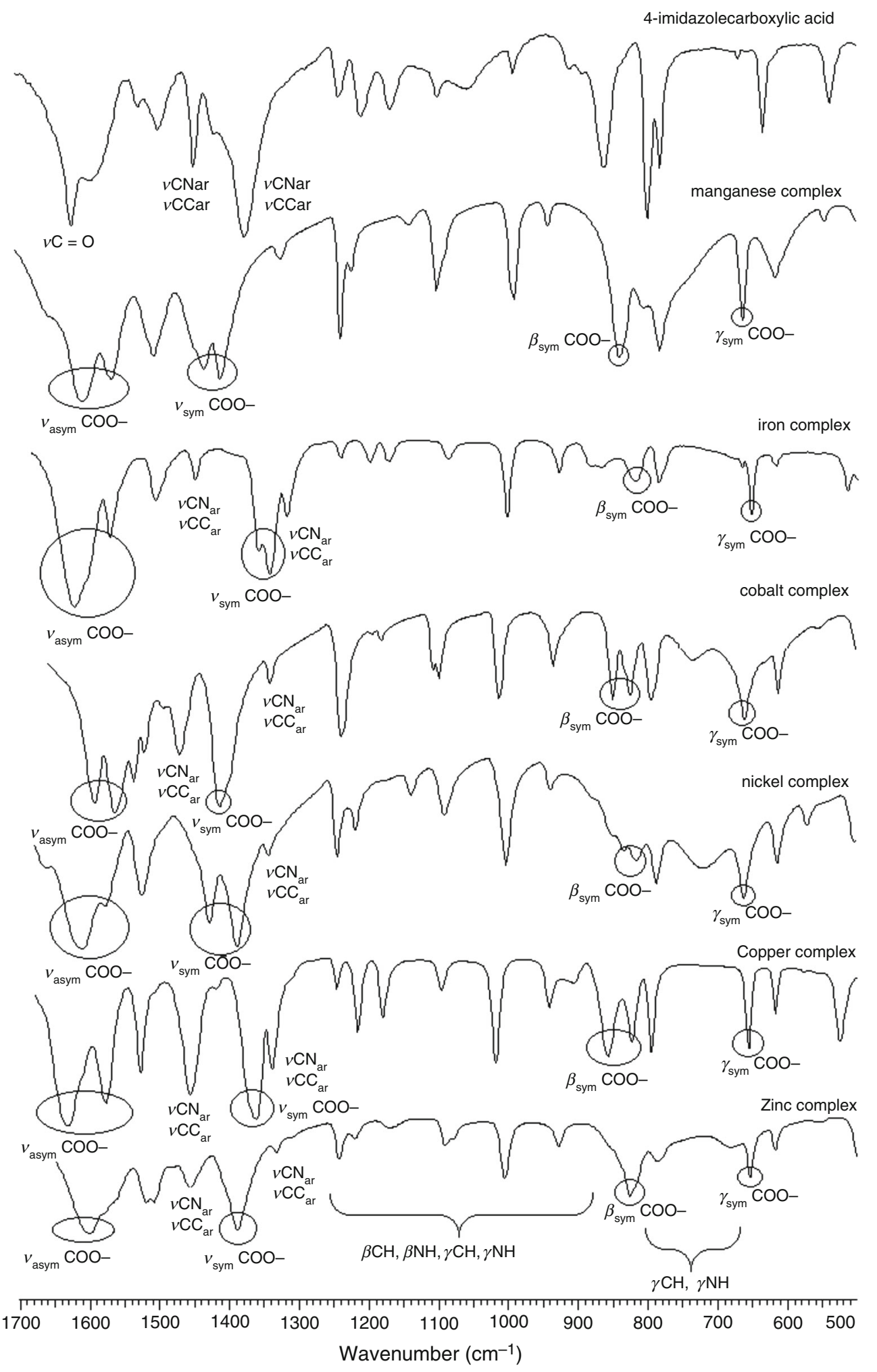

Fig. 3 IR spectra for 4-imidazolecarboxylic acid and their 3d-metal complexes

decomposition of the manganese complex, manganese carbonate $\mathrm{MnCO}_{3}$ was obtained probably due to the partial ionic character of the manganese compound [17]. The anhydrous compounds decompose in one step which corresponds to the sharp exothermic peaks in DSC curve (Fig. 8). They can be attributed to oxidation of organic 
Table 2 Spectral parameters (vibrations stretching the carboxylate anion) from the IR spectra of 4-imidazolecarboxylates and proposed type of coordination the metal to carboxylic group of the ligand

\begin{tabular}{|c|c|c|c|c|}
\hline Compound & $\begin{array}{l}\text { Asymmetric stretches of the } \\
\text { carboxylate anion } v_{\mathrm{as}}\left(\mathrm{COO}^{-}\right) \\
\text {Wavenumber/cm }\end{array}$ & $\begin{array}{l}\text { Symmetric stretches of the } \\
\text { carboxylate anion } v_{\mathrm{s}}\left(\mathrm{COO}^{-}\right) \\
\text {Wavenumber } / \mathrm{cm}^{-1}\end{array}$ & $\begin{array}{l}\text { Difference between the } \\
v_{\mathrm{as}}\left(\mathrm{COO}^{-}\right) \text {and } v_{\mathrm{s}}\left(\mathrm{COO}^{-}\right) \\
\text {Wavenumber } / \mathrm{cm}^{-1}\end{array}$ & $\begin{array}{l}\text { Proposed } \\
\text { coordination }\end{array}$ \\
\hline Sodium salt & 1576 & 1457 & 119 & Monodentate \\
\hline $\begin{array}{l}\text { Manganese } \\
\text { complex }\end{array}$ & 1603,1561 & 1429,1406 & 184,155 & Monodentate \\
\hline $\begin{array}{l}\text { Iron } \\
\text { complex }\end{array}$ & 1637,1584 & 1369,1354 & 268,230 & Monodentate \\
\hline $\begin{array}{l}\text { Cobalt } \\
\text { complex }\end{array}$ & 1585,1555 & 1406 & 179,149 & Monodentate \\
\hline $\begin{array}{l}\text { Nickel } \\
\text { complex }\end{array}$ & 1600,1568 & 1419,1381 & 181,187 & Monodentate \\
\hline $\begin{array}{l}\text { Copper } \\
\text { complex }\end{array}$ & 1623,1569 & 1355 & 268,214 & Monodentate \\
\hline $\begin{array}{l}\text { Zinc } \\
\text { complex }\end{array}$ & 1602 & 1388 & 214 & Monodentate \\
\hline
\end{tabular}

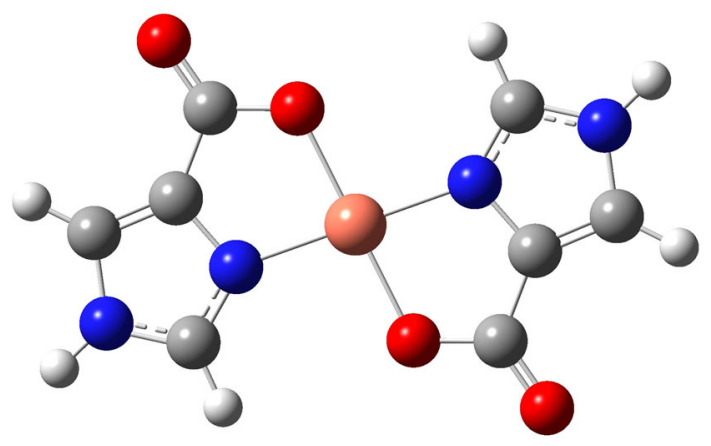

Fig. 4 Theoretical structure of copper 4-imidazolecarboxylate (calculated in B3LYP/6-311++G(p,d))

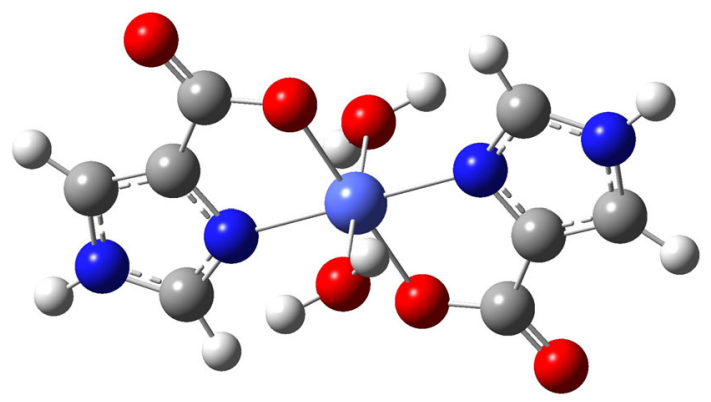

Fig. 5 Theoretical structure of cobalt 4-imidazolecarboxylate (calculated in B3LYP/6-311++G(p,d))

matter and the gaseous products that arise during thermal decomposition [22, 23]. If the thermal decomposition is conducted in an inert gas atmosphere (argon), other end products are created.
Thermogravimetric studies and elemental analysis showed that the complexes tested were hydrated (except for the copper complex). The degree of hydration wasone particle of water in the zinc and iron complexes, two water molecules in the cobalt complex and three molecules in the manganese and nickel complex. In the first stage, the endothermic processes of dehydration of complexes occur in only one step (for the hydrated complexes). For majority complexes, dehydration temperatures are higher than $100{ }^{\circ} \mathrm{C}$, what can point to the coordination character of water molecules.

The endothermic process of dehydration at low temperature with the onset temperatures of water evaporation at $90{ }^{\circ} \mathrm{C}$ was observed for manganese and iron complexes. This value shows the outer-sphere character of water molecules in the structure of manganese and iron complex. Zinc complex loses one molecule water in the temperature range $170-200{ }^{\circ} \mathrm{C}$; cobalt complex loses two molecules water in $180-200{ }^{\circ} \mathrm{C}$. Iron complex loses one molecule water in the temperature range $100-150{ }^{\circ} \mathrm{C}$; nickel complex lose three molecules water in $120-180{ }^{\circ} \mathrm{C}$. The manganese complex loses water in two stages. In the first stage, it loses one molecule of water in the temperature range of $90-150{ }^{\circ} \mathrm{C}$; in the second stage it loses two molecules of water in the range of $170-270{ }^{\circ} \mathrm{C}$. In the second stage of thermal decomposition (conducted in oxygen atmosphere), the anhydrous complexes are decomposed to the corresponding metal oxides (metal carbonate in case of decomposition of the manganese complex). During this process, decomposition products such as carbon monoxide and carbon dioxide and degradation products of the imidazole ring are released. 
Fig. 6 UV spectra for 4-imidazolecarboxylic acid and 3d-metal

4-imidazolecarboxylates

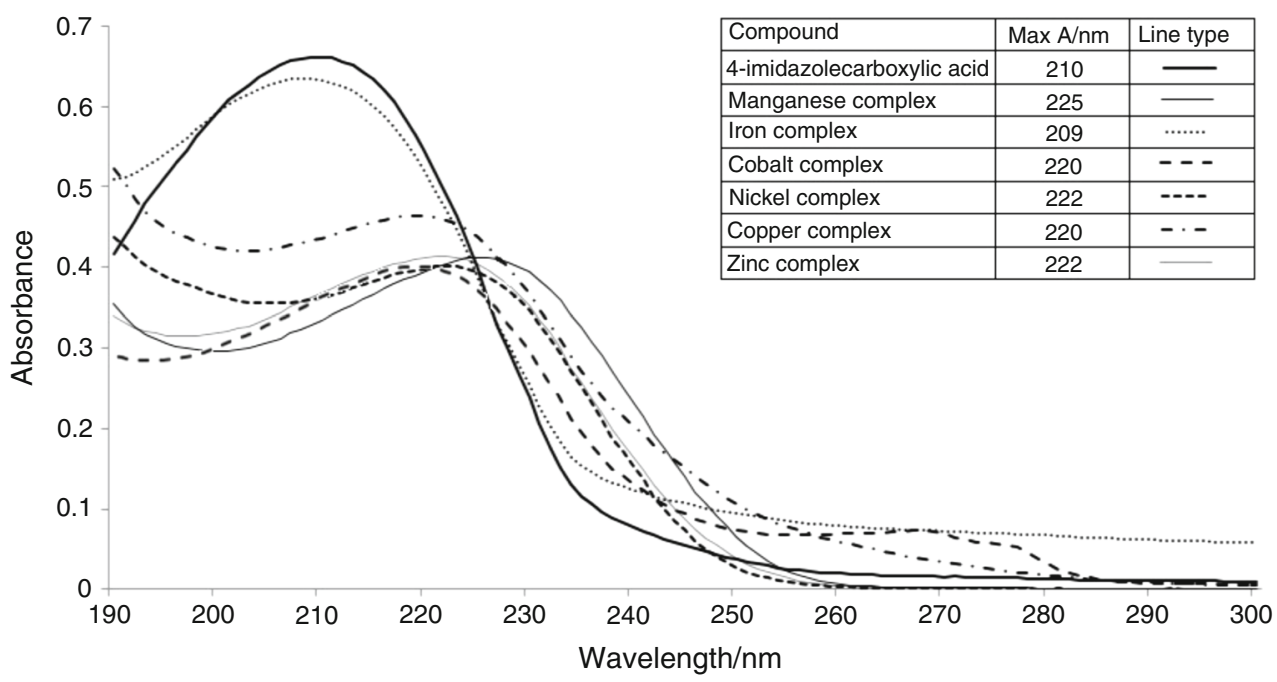

Table 3 Elemental analysis for manganese, iron, cobalt, nickel, copper and zinc

4-imidazolecarboxylate

\begin{tabular}{|c|c|c|c|c|c|c|c|c|}
\hline \multirow[t]{2}{*}{ Compound } & \multirow[t]{2}{*}{ Color } & \multirow[t]{2}{*}{ Yield (\%) } & \multicolumn{2}{|c|}{ Content $\mathrm{C} / \%$} & \multicolumn{2}{|c|}{ Content $\mathrm{H} / \%$} & \multicolumn{2}{|c|}{ Content N/\% } \\
\hline & & & Exp. & Calc. & Exp. & Calc. & Exp. & Calc. \\
\hline $\mathrm{MnL}_{2} \cdot 3 \mathrm{H}_{2} \mathrm{O}$ & Light yellow & 80 & 28.53 & 28.99 & 2.48 & 2.62 & 16.98 & 16.91 \\
\hline $\mathrm{FeL}_{3} \cdot \mathrm{H}_{2} \mathrm{O}$ & Yellow & $75-80$ & 35.82 & 35.31 & 2.65 & 2.45 & 19.89 & 20.60 \\
\hline $\mathrm{CoL}_{2} \cdot 2 \mathrm{H}_{2} \mathrm{O}$ & Purple & 85 & 30.05 & 30.27 & 2.41 & 2.52 & 17.43 & 17.66 \\
\hline $\mathrm{NiL}_{2} \cdot 3 \mathrm{H}_{2} \mathrm{O}$ & Green & $80-85$ & 28.14 & 28.68 & 2.47 & 2.69 & 16.06 & 16.73 \\
\hline $\mathrm{CuL}_{2}$ & Blue & $70-75$ & 32.67 & 33.60 & 2.03 & 2.10 & 18.98 & 19.60 \\
\hline $\mathrm{ZnL}_{2} \cdot \mathrm{H}_{2} \mathrm{O}$ & White & 80 & 30.88 & 31.42 & 2.12 & 2.29 & 18.02 & 18.33 \\
\hline
\end{tabular}

The TG and DTG curves of manganese complex are shown Fig. 7b. The DSC curves are shown in Fig. 8. $\mathrm{MnL}_{2} \cdot 3 \mathrm{H}_{2} \mathrm{O}$ decomposes (in oxygen atmosphere) in three stages in temperature range of $90-390{ }^{\circ} \mathrm{C}$. In a first and second step, followed by dehydration of the complex, the mass loss is 6.5 and $16.50 \%$ (calculated $6.10,16.31 \%$ ) for the first and second stage of dehydration, respectively. In the third stage of thermal decomposition, the imidazole ring and the carboxylate group are decomposed (temperature range is $280-390{ }^{\circ} \mathrm{C}$ ). Gaseous decomposition products are released and the final product is $\mathrm{MnCO}_{3}$ manganese carbonate. The mass loss is $66.92 \%$ (calculated $66.50 \%$ ). The final product is formed above $390{ }^{\circ} \mathrm{C}$. Thermal decomposition of the manganese complex (in argon atmosphere) takes place in several stages. The final product probably is manganese carbonate and residual carbon from the decomposition of carboxylic group.

The TG and DTG curves of $\mathrm{CoL}_{2} \cdot 2 \mathrm{H}_{2} \mathrm{O}$ complex are shown in Fig. 7d. DSC curves are shown in Fig. 8. The thermal decomposition of the cobalt complex occurs in three stages. In the first stage, dehydration takes place, whereby two molecules of water are detached. This process takes place between 170 and $200{ }^{\circ} \mathrm{C}$. The mass loss is $10.57 \%$ (calculated $11.35 \%$ ). At the next stage of thermal decomposition (at $255-370{ }^{\circ} \mathrm{C}$ ), the imidazole ring disintegrates. (The mass loss is $54.73 \%$.) The final stage is the thermal decarboxylation $\left(375-420{ }^{\circ} \mathrm{C}\right)$ leading to the final product- $\mathrm{CoO}$ cobalt oxide (mass loss $75.41 \%$ measured, 76.37—calculated).

The decomposition of the cobalt complex in argon atmosphere also occurs in several stages (Fig. 7d). After the dehydration step, the imidazole ring disintegrates and the decomposition takes place in subsequent steps. The final product of the thermal decomposition carried out at temperature higher than $850{ }^{\circ} \mathrm{C}$ is cobalt oxide and carbon residue, which has not been burned.

The TG and DTG curves of $\mathrm{NiL}_{2} \cdot 3 \mathrm{H}_{2} \mathrm{O}$ complex are shown in Fig. 7e. DSC curves are shown in Fig. 8. The thermal decomposition of the nickel complex also takes place in three stages. In the first stage, dehydration takes place at $120-180{ }^{\circ} \mathrm{C}$ (mass loss $16.62 \%$-measured, 16.13-calculated). In the second stage, the thermal decomposition of the imidazole ring $\left(240-365{ }^{\circ} \mathrm{C}\right.$ ) (mass loss $54.50 \%$ ) occurs. In the third stage of the thermal decomposition, the final product-nickel oxide $\mathrm{NiO}$ $\left(370-420{ }^{\circ} \mathrm{C}\right.$ ) (mass loss $77.72 \%$-measured, 77.69-calculated)—occurs. The thermal decomposition process carried out in an inert gas atmosphere takes place in several stages. These are: dehydration, thermal decomposition of the imidazole ring, decomposition of carbonates. The final 

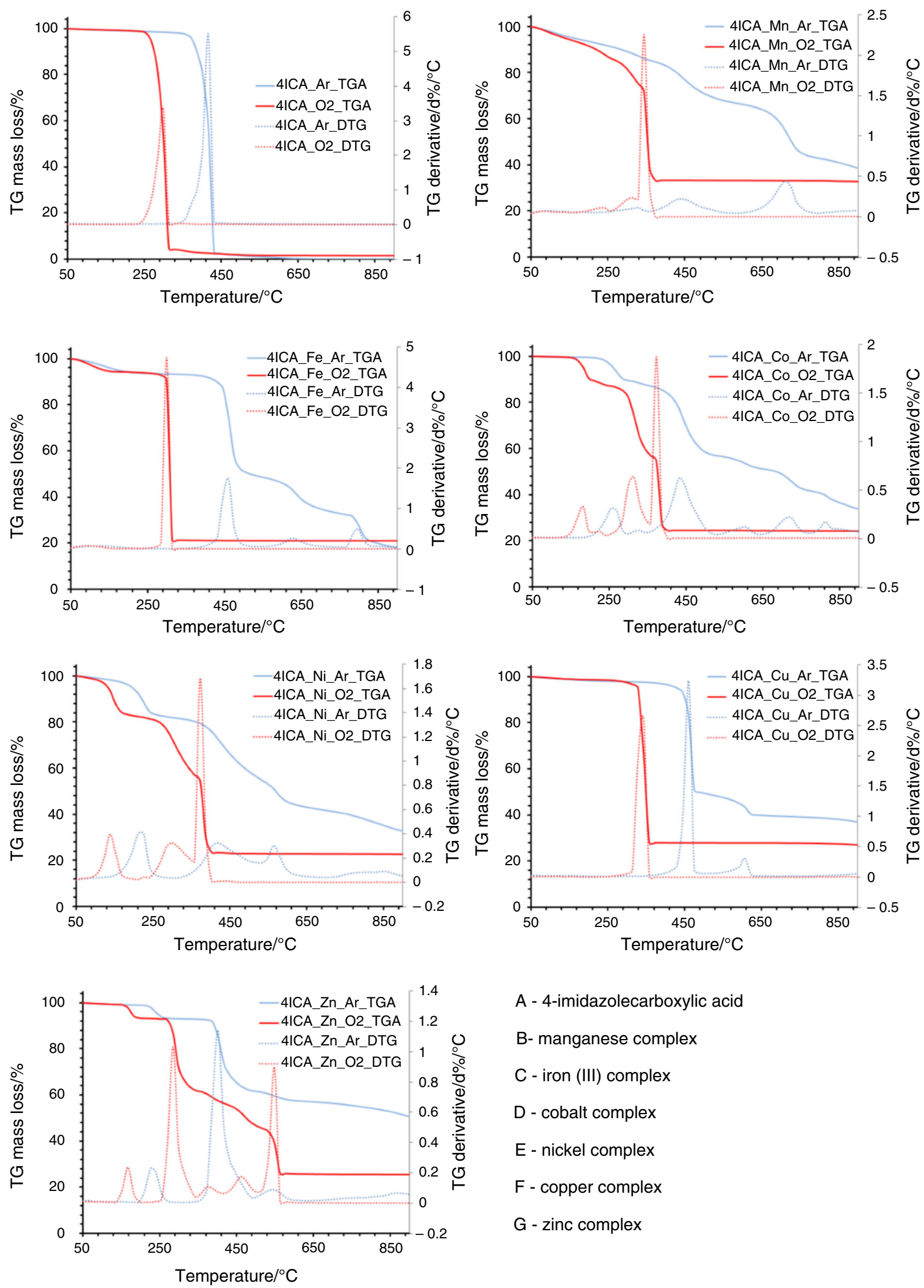
A - 4-imidazolecarboxylic acid
B- manganese complex
C - iron (III) complex
D - cobalt complex
E - nickel complex
F - copper complex
G - zinc complex

Fig. 7 TG/DTG curves of 4-imidazolecarboxylic acid and 4-imidazolecarboxylates (in oxygen atmosphere and argon atmosphere) 
product of the process (about $850{ }^{\circ} \mathrm{C}$ ) is nickel oxide and carbon residue.

The TG and DTG curves of $\mathrm{FeL}_{3} \cdot \mathrm{H}_{2} \mathrm{O}$ are shown in Fig. 7c. DSC curves are shown in Fig. 8. In the first stage of the thermal decomposition of the iron complex (in oxygen atmosphere), the dehydration occurs. At a temperature of $100-150{ }^{\circ} \mathrm{C}$, one molecule of the water is disconnected (mass loss 5.65\%-measured, 4.14-calculated). In the second, final product $\mathrm{Fe}_{2} \mathrm{O}_{3}$ (iron oxide) $\left(295-315{ }^{\circ} \mathrm{C}\right)$ is formed. The mass loss in this process is $78.95 \%$-measured, $80.25 \%$-calculated. The thermal decomposition of the iron complex is carried out in argon atmosphere in several stages. After thermal dehydration (above $400{ }^{\circ} \mathrm{C}$ ), there is a multistage decomposition of the complex. The thermal decomposition of the iron complex leads to the same products $\left(\mathrm{Fe}_{2} \mathrm{O}_{3}\right)$ when heated in an aerobic and anaerobic atmosphere. The TG and DTG curves of $\mathrm{CuL}_{2}$ are shown in Fig. 7f. DSC curves are shown in Fig. 8. The anhydrous copper complex undergoes thermal decomposition in a one step. The final product of copper complex decomposition is copper oxide $\mathrm{CuO}$. (This product is formed in the temperature range $330-370{ }^{\circ} \mathrm{C}$.)

Table 4 Thermoanalytical results (TG, DTG, DSC) for complexes of 4-imidazolecarboxylates (process in oxygen atmosphere)

\begin{tabular}{|c|c|c|c|c|c|c|c|c|}
\hline \multirow[t]{2}{*}{ Complex } & \multirow[t]{2}{*}{ Stage } & \multirow{2}{*}{$\begin{array}{l}\mathrm{TG} \\
T_{\text {range }} /{ }^{\circ} \mathrm{C}\end{array}$} & \multirow{2}{*}{$\begin{array}{l}\text { DTG (DSC) } \\
T_{\text {max. peaks }} /{ }^{\circ} \mathrm{C}\end{array}$} & \multirow[t]{2}{*}{ Peak nature } & \multicolumn{2}{|c|}{ Mass loss $/ \%$} & \multirow[t]{2}{*}{ Loss } & \multirow[t]{2}{*}{ Final residue } \\
\hline & & & & & Calc. & Found & & \\
\hline \multirow[t]{3}{*}{$\mathrm{Mn}(4-\mathrm{ICA})_{2} \cdot 3 \mathrm{H}_{2} \mathrm{O}$} & I & $90-150$ & $90(90)$ & Endo & 6.10 & 6.50 & $\mathrm{H}_{2} \mathrm{O}$ & \multirow[t]{3}{*}{$\mathrm{MnCO}_{3}$} \\
\hline & II & $170-270$ & $230(240)$ & Endo & 16.31 & 16.50 & $2 \mathrm{H}_{2} \mathrm{O}$ & \\
\hline & III & $280-390$ & $343(358)$ & Exo & 66.50 & 66.92 & $\mathrm{CO}_{2} ; \mathrm{CO} ;$ imid & \\
\hline \multirow[t]{2}{*}{$\mathrm{Fe}(4-\mathrm{ICA})_{3} \cdot \mathrm{H}_{2} \mathrm{O}$} & I & $100-150$ & 94 (79) & Endo & 4.14 & 5.65 & $\mathrm{H}_{2} \mathrm{O}$ & \multirow[t]{2}{*}{$\mathrm{Fe}_{2} \mathrm{O}_{3}$} \\
\hline & II & $295-315$ & $299(314)$ & Exo & 80.25 & 78.95 & $\mathrm{CO}_{2} ; \mathrm{CO} ;$ imid & \\
\hline \multirow[t]{3}{*}{$\mathrm{Co}(4-\mathrm{ICA})_{2} \cdot 2 \mathrm{H}_{2} \mathrm{O}$} & I & 170-200 & $182(182)$ & Endo & 11.35 & 10.57 & $2 \mathrm{H}_{2} \mathrm{O}$ & \multirow[t]{3}{*}{$\mathrm{CoO}$} \\
\hline & II & $255-370$ & $314(314)$ & Endo & - & 54.73 & imid & \\
\hline & III & $375-420$ & $373(387)$ & Exo & 76.37 & 75.41 & $\mathrm{CO}_{2} ; \mathrm{CO}$ & \\
\hline \multirow[t]{3}{*}{$\mathrm{Ni}(4-\mathrm{ICA})_{2} \cdot 3 \mathrm{H}_{2} \mathrm{O}$} & I & $120-180$ & $138(152)$ & Endo & 16.13 & 16.62 & $3 \mathrm{H}_{2} \mathrm{O}$ & \multirow[t]{3}{*}{$\mathrm{NiO}$} \\
\hline & II & $240-365$ & $299(314)$ & Endo & - & 54.50 & imid & \\
\hline & III & $370-420$ & $373(387)$ & Exo & 77.69 & 77.72 & $\mathrm{CO}_{2} ; \mathrm{CO}$ & \\
\hline $\mathrm{Cu}(4-\mathrm{ICA})_{2}$ & I & $330-370$ & $343(343)$ & Exo & 72.16 & 72.10 & $\mathrm{CO}_{2} ; \mathrm{CO} ;$ imid & $\mathrm{CuO}$ \\
\hline \multirow[t]{4}{*}{$\mathrm{Zn}(4-\mathrm{ICA})_{2} \cdot \mathrm{H}_{2} \mathrm{O}$} & I & 170-200 & $167(182)$ & Endo & 5.89 & 6.72 & $1 \mathrm{H}_{2} \mathrm{O}$ & \multirow[t]{4}{*}{$\mathrm{ZnO}$} \\
\hline & II & $270-360$ & $284(285)$ & Endo & - & 38.50 & imid & \\
\hline & III & $360-535$ & $360(475)$ & Exo & - & 65.97 & $\mathrm{CO}_{2} ; \mathrm{CO}$ & \\
\hline & IV & $540-580$ & 549 (549) & Exo & 73.37 & 74.11 & & \\
\hline 4-ICA & I & $270-320$ & 299 (299) & Exo & 100 & 100 & $\mathrm{CO}_{2} ; \mathrm{CO} ;$ imid & - \\
\hline
\end{tabular}
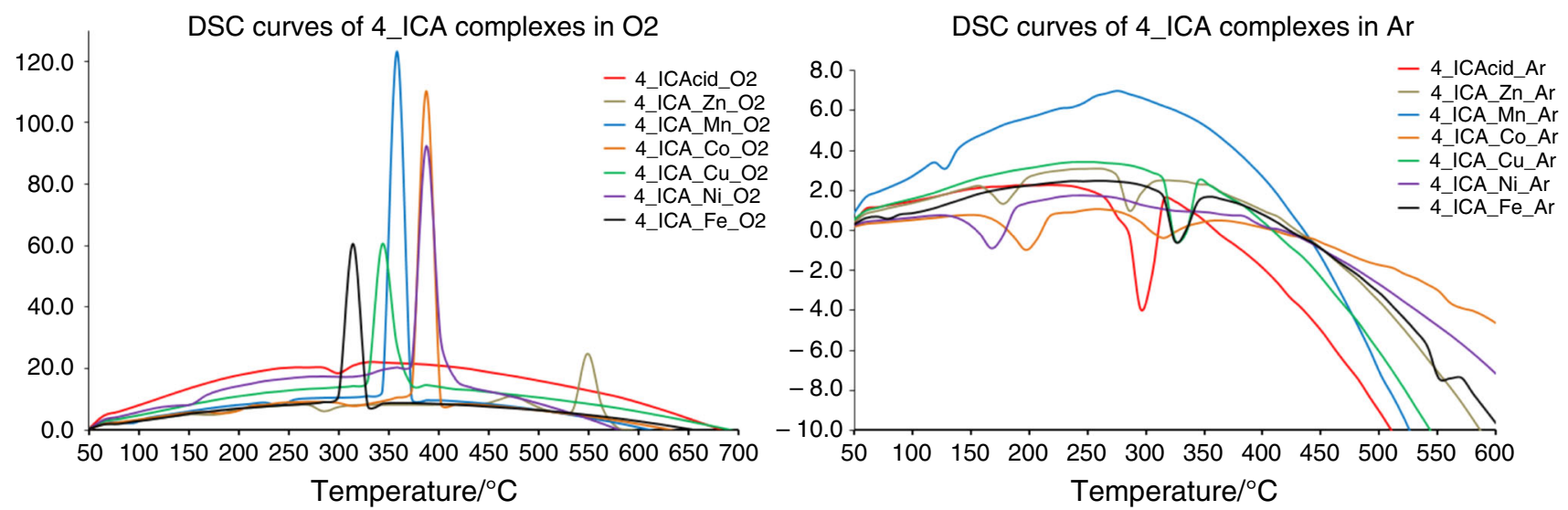

Fig. 8 DSC curves of 4-imidazolecarboxylic acid and 4-imidazolecarboxylates (in oxygen atmosphere and argon atmosphere) 
The mass loss in this process is $72.10 \%$-measured, $72.16 \%$ - calculated. Heating the copper complex under an argon atmosphere leads to the formation of $\mathrm{CuO}$ copper oxide and carbon residue. The TG and DTG curves of $\mathrm{ZnL}_{2} \cdot \mathrm{H}_{2} \mathrm{O}$ are shown in Fig. $7 \mathrm{~g}$. DSC curves are shown in Fig. 8. The zinc complex undergoes thermal decomposition (in oxygen atmosphere) in several stages. In the first stage, thermal dehydration occurs $\left(170-200{ }^{\circ} \mathrm{C}\right.$ ) (mass loss $5.89 \%$-measured, 6.72-calculated). In subsequent steps, the thermal decomposition of the imidazole ring and subsequent decomposition of the zinc carbonate with the release of carbon oxides are followed. The final product of the process is zinc oxide. (This product is formed in the temperature range $540-580{ }^{\circ} \mathrm{C}$ ) (mass loss $73.37 \%$ measured, 74.11—calculated.) During the thermal decomposition of the zinc complex in an argon atmosphere, dehydration occurs in the first stage. The next step is the thermal decomposition of the imidazole ring. The final product is zinc carbonate.

The most thermally stable complex is the iron complex. The decomposition process of iron 4-imidazolecarboxylate starts above $275^{\circ} \mathrm{C}$. The least stable is manganese complex. (The decomposition starts above $180{ }^{\circ} \mathrm{C}$ ).

\section{Conclusions}

1. The thermal stability of selected $3 \mathrm{~d}$ transitional complexes (with manganese, iron, cobalt, nickel, copper and zinc) was compared. The study was conducted in an oxygen atmosphere and in an inert gas atmosphere (in argon). Composition of complexes and their structure (type of the ligand-metal coordination) was determined using spectroscopic methods (infrared and Raman spectroscopy). A detailed analysis of infrared spectra and UV spectra of the complexes in aqueous solutions was performed to determine the effect of metals on the change in the electronic charge distribution of the ligand under complexation. Theoretical calculations for imidazole, 4-imidazolecarboxylic acid, its sodium salt, copper and cobalt complexes have been performed for the assignment and analysis of the infrared and Raman spectra of studied compounds.

2. Based on the spectroscopic studies, the ligand (4imidazolecarboxylic acid) has been found to coordinate the metal by the carboxylate group (monodentate type of coordination) and the nitrogen atom of imidazole ring.

3. On the basis of spectroscopic studies (IR, Raman) and theoretical calculations, it was found that $3 \mathrm{~d}$-transition metals influence the electronic charge distribution of the aromatic ring of ligand. Under the influence of the
$3 \mathrm{~d}$ metals, the aromaticity of 4-imidazolecarboxylic acid ligand increases.

4. Based on the elemental and thermal analysis, it was found that the complexes were hydrated (except for the copper complex).

5. The products of thermal decomposition of investigated complexes conducted in the oxygen atmosphere at $50-850{ }^{\circ} \mathrm{C}$ are metal oxides. (In the case of thermal decomposition of the manganese complex, manganese carbonate $\mathrm{MnCO}_{3}$ was obtained). In the case of an anaerobic process of the thermal decomposition, the final products can be metal oxides and unburned carbon residues.

6. The most thermally stable complex is the iron complex. The process of its decomposition begins above $275{ }^{\circ} \mathrm{C}$. The least stable is manganese complex. (The decomposition starts above $180{ }^{\circ} \mathrm{C}$.)

Acknowledgements Studies have been carried out in the framework of the work no. S/WBiIŚ/3/2017 and financed from the funds for science Ministry of Science and Higher Education.

Open Access This article is distributed under the terms of the Creative Commons Attribution 4.0 International License (http://creative commons.org/licenses/by/4.0/), which permits unrestricted use, distribution, and reproduction in any medium, provided you give appropriate credit to the original author(s) and the source, provide a link to the Creative Commons license, and indicate if changes were made.

\section{References}

1. Shingalapur RV, Hosamani KM, Keri RS. Synthesis and evaluation of in vitro anti-microbial and anti-tubercular activity of 2-styryl benzimidazoles. Eur J Med Chem. 2009;44:4244-8.

2. Refaat HM, Europ J. Synthesis and anticancer activity of some novel 2-substituted benzimidazole derivatives. Med Chem. 2010;45:2949-56.

3. Roman G, Riley JG, Vlahakis JZ, Kinobe RT, Brien JF, Nakatsu $\mathrm{K}$, Szarek WA. Heme oxygenase inhibition by 2-oxy-substituted 1-(1H-imidazol-1-yl)-4-phenylbutanes: effect of halogen substitution in the phenyl ring. Bioorg Med Chem. 2007;15:3225-34.

4. Venkatesan AM, Agarwal A, Abe T, Ushirogochi HO, Santos D, Li Z, Francisco G, Lin YI, Peterson PJ, Yang Y, Weiss WJ, Shales DM, Mansour TS. 5, 5, 6-Fused tricycles bearing imidazole and pyrazole 6-methylidene penems as broad-spectrum inhibitors of $\beta$-lactamases. Bioorg Med Chem. 2008;16:1890-902.

5. Shalini K, Sharma PK, Kumar N. Imidazole and its biological activities: a review. Der Chem Sin. 2010;1(3):36-47.

6. Salerno L, Pittala V, Romeo G, Modica MN, Marazzo A, Siracusa MA, Sorrenti V, Di Giacomo C, Vanella L, Parayath NN, Greish K. Novel imidazole derivatives as heme oxygenase-1 (HO-1) and heme oxygenase-2 (HO-2) inhibitors and their cytotoxic activity in human-derived cancer cell lines. Eur J Med Chem. 2015;96:162-72.

7. Bhatnagar A, Sharma PK, Kumar N. A review on "Imidazoles": Their chemistry and pharmacological potentials. Int J Pharm Tech Res. 2011;3(1):268-82. 
8. Pozharski AF, Soldatenkov AT, Katritzky AR. Heterocycles in life and society: an introduction to heterocyclic chemistry, biochemistry and applications. Chichester: Wiley; 2011.

9. Pilling ED, Bromleychallenor KAC, Walker $\mathrm{CH}$, Jepson PC. Mechanism of synergism between the pyrethroid insecticide $\lambda$ cyhalothrin and the imidazole fungicide prochloraz, in the honeybee (Apis mellifera L.). Pestic Biochem Physiol. 1995;5(1):1-11.

10. Li LF, Wang H, Zhang J, Ma C, Li YY, Wang L, Liang SK, Jin HT, Liu SJ, Zhu MC, Gao EJ. Syntheses, characterization, interaction with DNA, cytotoxic and apoptosis of two novel complexes of $\mathrm{Zn}(\mathrm{II})$ and $\mathrm{Mn}(\mathrm{II})$ with 2-methyl-1H-4,5-imidazoledicarboxylic acid. Eur J Med Chem. 2015;92:295-301.

11. Ma C, Liang SK, Zhao FC, Meng Y, Li YY, Zhu MC, Gao EJ. Cadmium (II) complex with 2-methyl-1H-4,5-imidazoledicarboxylic acid ligand: synthesis, characterization, and biological activity. J Coord Chem. 2014;67(21):3551-64.

12. Galvan-Tejada N, Bernes S, Castillo-Blum SE, Nöth H, Vicente R, Barba-Behrens N. Supramolecular structures of metronidazole and its copper(II), cobalt(II) and zinc(II) coordination compounds. J Inorg Biochem. 2002;91:339-48.

13. Boskovic C, Folting K, Christou G. Tetranuclear manganese carboxylate clusters with imidazole-carboxylate chelating ligands. X-ray crystal structure of the 4-imidazoleacetate complex. Polyhedron. 2000;19:2111-8.

14. Montes-Ayala J, Escartín-Guzmán C, Castillo-Blum SE, Rodríguez-Hernández EO, Bernès S, Rosales-Hoz MJ, Barba-Behrens N. Crystal structure, solid state and solution characterisation of copper(II) coordination compounds of ethyl 5-methyl-4-imidazolecarboxylate (emizco). J Inorg Biochem. 2005;99(8):1676-84.

15. Barrera-Guzmán VA, Ramírez-Trejo R, Rodríguez-Hernández EO, Barba-Behrens N. 2D and 3D supramolecular structures of trans-and cis-octahedral coordination compounds of ethyl-5methyl-4-imidazolecarboxylate with transition metal ions. J Mex Chem Soc. 2012;56(1):51-7.

16. Shimizu E, Kondo M, Fuwa Y, Sarker RP, Miyazawa M, Ueno M, Naito T, Maeda K, Uchida F. Synthesis and crystal structures of metal complexes with 4, 5-imidazole-dicarboxylate chelates: self-assembled structures via $\mathrm{NH}$... O C intermolecular hydrogen bonds. Inorg Chem Commun. 2004;7(11):1191-4.

17. Premkumar T, Govindarajan S, Pan WP, Xie R. Preparation and thermal behaviour of transition metal complexes of 4, 5-imidazoledicarboxylic acid. $\mathrm{J}$ Therm Anal Calorim. 2003;74(1):325-33.

18. Li ZY, Zhang ZM, Dai JW, Huang HZ, Li XX, Yue ST, Liu YL. Three novel lanthanide complexes with imidazole-4, 5-dicarboxylate ligand: hydrothermal syntheses, structural characterization, and properties. J Mol Struct. 2010;963(1):50-6.

19. Świderski G, Kalinowska M, Wojtulewski S, Lewandowski W. Experimental (FT-IR, FT-Raman, 1H NMR) and theoretical study of magnesium calcium, strontium, and barium picolinates. Spectrochim Acta Part A. 2006;64:24-33.
20. Świderski G, Kalinowska M, Malejko J, Lewandowski W. Spectroscopic (IR, Raman, UV and fluorescence) study on lanthanide complexes of picolinic acid. Vib Spectrosc. 2016;87:81-7.

21. Jabłońska-Wawrzycka A, Zienkiewicz M, Barszcz B, Rogala P. Thermoanalytical study of selected transition bivalent metal complexes with 5-carbaldehyde-4-methylimidazole. J Therm Anal Calorim. 2012;109(2):735-43.

22. Świderski G, Kalinowska M, Rusinek I, Samsonowicz M, Rzączyńska Z, Lewandowski W. Spectroscopic (IR, Raman) and thermogravimetric studies of $3 \mathrm{~d}$-metal cinchomeronates and dinicotinates. J Therm Anal Calorim. 2016;126(3):1521-32.

23. Świderski G, Lewandowska H, Świsłocka R, Wojtulewski S, Siergiejczyk L, Wilczewska A. Thermal, spectroscopic (IR, Raman, NMR) and theoretical (DFT) studies of alkali metal complexes with pyrazinecarboxylate and 2, 3-pyrazinedicarboxylate ligands. J Therm Anal Calorim. 2016;126(1):205-24.

24. Frisch M, Trucks GW, Schlegel HB, Scuseria GE, Robb MA, Cheeseman JR, Scalmani G, Barone V, Mennucci B, Petersson GA. Gaussian 09, revision A, vol. 02. Wallingford: Gaussian Inc; 2009. p. 227-38.

25. Polat T, Yurdakul S. DFT, FT-IR and FT-Raman investigations of 1-methyl-2-imidazolecarboxaldehyde. J Mol Struct. 1053;2013:27-37.

26. Van Bael MK, Smets J, Schoone K, Houben L, McCarthy W, Adamowicz L, Nowak MJ, Maes G. Matrix-isolation FTIR studies and theoretical calculations of hydrogen-bonded complexes of imidazole. A comparison between experimental results and different calculation methods. $J$ Phys Chem A. 1997;10(13):2397-413.

27. Rode JE, Dobrowolski JC, Jamróz MH, Borowiak MA. Theoretical IR, Raman and NMR spectra of 1, 2-and 1, 3-dimethylenecyclobutane. Vib Spectrosc. 2001;25:133-49.

28. Nakamoto K. Infrared and Raman spectra of inorganic and coordination compounds. New York: Wiley; 1986.

29. Deacon GB, Philips RJ. Relationships between the carbon-oxygen stretching frequencies of carboxylato complexes and the type of carboxylate coordination. Coord Chem Rev. 1980;33(3):227-50.

30. Lewandowski W, Kalinowska M, Lewandowska H. The influence of metals on the electronic system of biologically important ligands. Spectroscopic study of benzoates, salicylates, nicotinates and isoorotates. Review. J Inorg Biochem. 2005;99:1407-23.

31. Lewandowski W, Fuks L, Kalinowska M, Koczoń P. The influence of selected metals on the electronic system of biologically important ligands. Spectrochim Acta A. 2003;59(14):3411-20.

32. Lewandowski W, Barańska H. Comparison of the influence of silver, iron (III) and chromium (III) on the aromatic system of benzoic and salicylic acids in hydrated and anhydrous complexes. Vib Spectrosc. 1991;2:211-20.

33. Lewandowski W, Barańska H, Mościbroda P. Vibrational study of nicotinic acid complexes with different central ions. J Raman Spectrosc. 1993;24:819-24. 